\title{
Paulo Henriques Britto
}

\section{Como você pensa a relação entre o tempo literá- rio e o tempo histórico?}

Eu diria que a relação é variável, dependendo da obra em questão. Em alguns casos, o diálogo da obra com o seu tempo é parte integrante de seu significado - pensemos nos poemas de A rosa do povo de Drummond. Já em outros, a obra parece dialogar mais com outras obras, num plano sincrônico, do que com seu momento histórico; para ficar com o mesmo poeta, um bom exemplo seria "A máquina do mundo".

\section{Quais procedimentos sua obra adota diante de} um mundo em que predominam a ação econômica e a espetacularização da arte?

Uma das vantagens da poesia é ela depender minimamente de investimentos, já que prescinde de qualquer tecnologia mais complexa do que lápis e papel. Além disso, do modernismo para cá, a tendência autorreflexiva da poesia teve o efeito de restringir seu público de tal modo que o poeta, por não ter nenhuma pretensão de viver do seu trabalho artístico, pode se dar ao luxo de escrever exatamente o que deseja, sem se preocupar com o gosto do público.

\section{Qual reflexão sua obra produz sobre a tradição literária brasileira?}

Comecei a escrever num momento em que as vanguardas viviam seu último momento de glória. A tropicália estava no ar, e nos meios poéticos desenrolava-se o debate entre concretismo, práxis e poema-processo. Mas eu pensava - como penso ainda agora - que em arte, como em qualquer campo, é preciso começar do começo. Eu tinha consciência de que querer inventar uma nova poesia que radicalizasse tudo o que as vanguardas já haviam feito antes de aprender os rudimentos da composição em redondilha maior era como pretender criticar as últimas produções filosóficas da Rive Gauche sem ter as mais vagas noções de Platão e Aristóteles. Assim, desde o início eu quis fazer uma leitura cuidadosa dos poetas que mais me interessavam - não apenas da tradução luso-brasileira, mas também da anglo-americana, por ter tido formação bilíngue - e tentar desenvolver uma linguagem própria a partir dessas leituras. Creio que minha poesia está em diálogo constante com alguns poetas de línguas portuguesa $\mathrm{e}$ inglesa, principalmente Pessoa, Drummond e Cabral entre os luso-brasileiros, e Dickinson e Stevens entre os anglo-americanos. O que me interessa da tradição modernista dos meus dois idiomas é acima de tudo a recusa às pretensões do sublime e do inefável. Minha poesia utiliza uma linguagem coloquial tensionada para tratar de questões da existência e da linguagem. 


\section{Como você pensa a forma literária?}

No meu caso, a opção pelo uso de elementos tradicionais - métrica, rima, estrofação - tem a ver com a necessidade de impor obstáculos à fluidez natural da escrita. Para mim, é a dificuldade imposta pela forma que faz com que a escolha de palavras escape dos caminhos mais óbvios. Mas tendo a usar o repertório de modo não tradicional, adaptando e distorcendo os elementos da tradição: formas e não fôrmas.

Paulo Henriques Britto (1951) publicou os livros de poesia Liturgia da matéria (Civilização Brasileira, 1982), Mínima lírica (Duas Cidades, 1989), Trovar claro (Companhia das Letras, 1997), Macau (Companhia das Letras, 2003), Tarde (Companhia das Letras, 2007); e um de contos, Paraísos artificiais (Companhia das Letras, 2004). Exímio tradutor, verteu para o português autores como Elizabeth Bishop, Wallace Stevens, Byron, Thomas Pynchon e William Faulkner, entre outros. 